\title{
THE DIS-(OTHERLY)ABLED AND PUBLIC MORALITY
}

\author{
Nico Koopman \\ Department of Ecclesiology and Systematic Theology \\ Stellenbosch University
}

\begin{abstract}
This article investigates the following question: How do disabled people and the response of Christians to them influence public morality? In a first round it is argued that the dominant ethical approach to health care, which is an approach that functions within the modern or liberal approach to morality, does not produce an adequate description of and response to the challenge posed by disabled people. The understanding of morality, anthropology and theology (specifically the doctrine of God) is consecutively described and evaluated. Morality, it is argued, is more than the narrow morality of the modern paradigm, which focuses only on the moral principles, and rules, which enable a society to exist without conflict and violence. Morality is broader. It has to do with the underlying perspectives of religious and nonreligious traditions on the nature of the good life, good societies and good people. Morality in the sphere of medical care is also wide morality. With regard to anthropology it is argued that the worth of human beings is not defined by their capacity of self-consciousness and reflective thinking, but by their vulnerability and their dependence upon each other. The Trinitarian basis of this anthropology is investigated. In a final round the implications of this alternative understanding of morality, anthropology and theology for the ethical challenges posed by disabled people are outlined. The meaning of these challenges for public morality is finally spelled out.
\end{abstract}

\section{The inadequacy of the dominant approach to morality}

The dominant approach to morality in the Western world since the Enlightenment entails that morality is limited to the guidelines, rules, rights and duties without which harmonious life in the midst of conflicting interests is not possible. This morality, which is called the narrow, public or social morality, is based on the conviction that it is possible to get knowledge of what is good and right without dependence on religious or nonreligious traditions. The morally good can be determined by using the rational capacities, which are common to human beings. Morality, therefore, is secular and it is universal. ${ }^{1}$ It is secular

1. The Dutch theologian, Harry Kuitert argued in various works over many years in favour of the secularity and universality of morality (cf.bibliography). One of his basic presuppositions is the autonomy of morality and of individuals. Morality is independent from religious and nonreligious traditions. In terms of the so-called creational redemption (skeppingsheil) morality is a gift from God to all human beings, whether they are religious or not (Alles is politiek, maar politiek is niet alles). Human beings can access this moral knowledge, knowledge about right and wrong, in independence from religious or nonreligious traditions by merely using their rational capabilities. Since almost all human beings, despite their plurality of religious, philosophical, cultural, economic and ethnic plurality share these rational capabilities the moral knowledge they acquire are universally accessible and applicable. Kuitert leaves room for difference about the application of moral principles to various situations, but there is, according to him, universal consensus on moral principles, specifically the following three: respect for life, respect for the property of people (including their bodies) and respect for truth (Morele consensus: mogelijkheden en grenzen.). The North American theologian, Lewis Smedes, adds love and justice to this list (Choices). Only where these moral principles are adhered to in deciding on moral behaviour is there a possibility of solving conflicts and of social cooperation amongst a plurality of role players. 
because of its independence from religious traditions and universal because all human beings with rational capabilities can acquire this knowledge. By employing this approach to morality conflicts, which originate in the plurality of traditions can be avoided and social cooperation in serving the needy and building a good society can be assured.

This narrow approach to morality is questioned in various circles. Theologians from various strands plead for the recognition of the so-called wide approach to morality which concerns itself, on the basis of perspectives from religious and nonreligious traditions, with questions about the good life, about the meaning and purpose of human life. The Dutch theologian, A Musschenga, unmasks the inadequacy of the narrow approach. He pleads for a historic-dynamic relation between religion and morality, which entails that the internal conversation about views of life within a tradition is not separated from the external dialogue with other traditions. An internal conversation without external dialogue leads to isolationism and external dialogue without internal conversation with the own resources of the tradition leads to emptiness (1989:176). The Danish theologian, Arne Rasmusson, appeals to David Schmidt for his suggestion of an edifying approach to morality, rather than a systematic one. The systematic approach functions with the presupposition of a universal standard to which all thought must conform whilst the edifying approach makes room for particularity, for a diversity of views and for dialogue (Rasmusson 1994:229). Stanley Hauerwas is perhaps the person who, more than any other, unmasks the inadequacy of the liberal approach to morality. He is of opinion that it is not possible to make morally good decisions and to act appropriately without attending to religion-dependent themes such as, firstly, the vision, virtue, character and integrity of the moral agent, secondly, the character forming narratives, thirdly the communities within which moral and character formation take place and lastly the theological basis of morality (cf. my dissertation on amongst others the ethics of Hauerwas, entitled Dade of deugde?) Where the narrow approach only focuses on decisions and actions, the wide approach makes room for the moral agents, their narratives, traditions and communities as well as the questions forthcoming from this broader sphere. Wide morality focuses primarily on the people and the communities in which they are formed. It has to do with the decisions we take, but more so with the type of people we are and the type of societies we envisage.

The narrow approach to morality is also the dominant one in the field of health care ethics. In various publications on medical ethics Hauerwas pleads that the scope of morality be broadened. With regard to abortion, for instance, he argues that not only questions that deal with rights, moral rules and decisions should be addressed. Questions, which have to do with perspectives from religious traditions, specifically the Christian tradition, should be the primary questions in the discourse. Consequently we should ask what type of people Christians are: are they a type of community that is capable of sustaining the practice of hospitality to new life (Hauerwas 1993).

The Dutch theologian Hans Reinders also pleads for the broadening of the scope of morality with regard to ethical discourse about disabled people. He focuses his views on people with mental disabilities. ${ }^{2}$ Reinders indicates that more than 75 percent of publications in ethics during the 1970s and 80s that deal with the topic of disabilities or handicaps focused on questions derived from the narrow approach, questions such as "Under what circumstances should euthanasia be considered?" and "When should so-called non-treatment decisions be made?" (2000:5). Reinders argues that the questions of the wide morality should also be applied to the moral discourse about people with disabilities. Questions in

2. Reinders occupies the Willem van den Bergh chair of Ethics and Mental Disability at the Vrije Universiteit in Amsterdam. 
the bioethical discourse should not only deal with the rights and duties of the so-called primary agents, like researchers, doctors, patients, insurance companies and employers who use genetic information because they are interested in risk assessment with regard to health. Neither should it only deal with eugenics (the question as to whether people may use genetic information for reasons of enhancing certain desired features in their offspring) privacy (the question as to what extent doctors must respect the private lives of their patients' families where they have diagnosed a genetic disorder), non-directivity (the question as to whether genetic counseling ought to be guided by particular values about responsible reproductive choices), the right not to know (the question as to whether people at risk of genetically affected offspring should seek information about possible future risk for their children), or the right to health care provisions (the question as to whether health insurance premiums may be adjusted for the carriers of genetic disorders) (2000:ix). This way of phrasing the ethical questions with regard to disabled people causes Reinders to remark as follows: "Whenever the disabled appear in the bioethical literature, their existence appears as part of what seems to be the problem" (2000:x).

Reinders suggests that questions derived from the wide morality, such as "Does using genetic testing for reasons of preventing a disabled life imply a negative evaluation of the lives of handicapped people?" also enter the bioethical discourse (2000:ix-x). In the same vein Hauerwas suggests that questions with regard to disabled people such as the following should also be grappled with: What does our care for the disabled reflect about our views about the good that Christians should do as opposed to the question about what is humanly possible? What does it reflect about our views on weak and strong, on what constitutes quality of life? What does this care reflect about our unique contribution to the good society? What does the care for the disabled say about our care for children, what does it say about our ethics of responsible parenthood? What does it say about our view on health, suffering and the relation between caring and curing? What does our problematizing of the existence of handicapped people say about the moral culture of our society (Hauerwas 1986:15, 182-188; 1987:591)?

To discuss the ethical challenges posed by people with disabilities within the framework of the wide morality requires a revaluation of our anthropology (understanding of humanity) and theology (understanding of God). On this task we embark in the following paragraphs.

\section{Humans - rational and independent beings?}

Modern thought locates the value, worth and essence of human beings in their potential to function rationally, autonomously and independently. The two North American theologians, Bruce Birch and Larry Rasmussen (1989:115) describe this anthropology of modern thought as follows:

There is, they contend, an essential human nature we all share. It exists quite apart from the peculiarities of time, place, and circumstance. This nature can be apprehended with the shared faculty of human reason and should be the basis for deriving common moral postulates, which would then be universal and more trustworthy than any principles grounded in the arbitrary and contingent nature of people's highly distinctive beliefs, character, and stories (italics NK).

The most important philosopher of the Enlightenment, Immanuel Kant, laid the foundation for this definition of humanity in terms of rational capacities. He argued that human beings can only come of age if they show the courage to be served by autonomous reason and not by any external source of authority - Aude sapere (quoted by Reinders 1993:164). 
The variety of disabled people do not pass these modernistic criteria for true humanity. The North American theologian Christine Smith states that people with disabilities do not pass these modernistic criteria for being fully human. "For many people with disabilities the myth of privatized living is not only shattered, but has never existed. As people with disabilities speak about limited mobility, attendant care, institutionalized living, and daily threats of death, the myth of total independence is exposed for the lie it is. The cultural myth of individual control becomes absurd" (Smith 1992:36). ${ }^{3}$

Reinders states that health care ethics has been dominated for the past three decades by the modern moral ideal of independent existence. Human beings should take decisions with regard to their medical treatment rationally and autonomously (Reinders 1996:2). The main task of health care is to free the patient from dependency and to put them in a position where they can negotiate as clients on an equal basis with the health caregivers about their treatment. Rights and laws are to be passed which assure that patients can act with selfdetermination and autonomy (Reinders 1996:14).

Although Reinders admits that patient rights are important to protect handicapped people against abuse, he is of opinion that a health care ethics that is based on rights and that has a negative view of dependence is not adequate. People with disabilities need not only rights, but more than that they need involvement, commitment, faithfulness and love (Reinders 1996:15-16). An adequate ethical response to disabled people can only be arrived at if the dependence of human beings is not viewed negatively. This requires a break with the dominant modern anthropology of rationality, autonomy and independence. With an appeal to the ethicist Joan Tronto he argues that the one fundamental feature of human beings should not be independence, but care. Care is the result of the acknowledgement that we can never be fully autonomous, that we need each other, that we exist in a condition of interdependence (Reinders 1996:16-17). According to Reinders the idea of human freedom as rational autonomy and independence is an aporia, since human beings are not able to subject all conditions of their existence to their reason. These conditions include the contingent and finite nature of our existence, as well as the external limitation of our freedom in relation to others and the internal limitation of our freedom, which is caused by our lack of self-knowledge (1996:32,61).

Hauerwas (1986:13-14) shares this plea for the redefinition of human beings in terms of interdependence and care. He is of opinion that the freedom and autonomy, which enable us to decide for ourselves on questions such as when to terminate a pregnancy, prevent us from negotiating the limits (i.e. dependence) and possibilities of this existence in a just and caring fashion. The freedom to merely choose for or against contraception prevents us from discussing the question about why we ought to be open to having and caring for children at all (Hauerwas 1986:19).

Various authors develop a theological basis for this anthropology of interdependence and care. Reinders' trinitarian approach, that is described and evaluated in the next para-

3. Smith pleads that the variety of disabilities be recognized and that disabilities and people with disabilities not be generalized and stereotyped, but that the particularity of not only a specific disability but also of the life of a specific person with a disability be heard, read and known (1992:21-30). This plea for particularity is affirmed by a woman with a disability who is quoted by Smith (1992:21-22): "So many factors influence how we experience our disabilities. Money. Degrees of mobility. Relationships. Community structures. Cultural/ethnic/racial backgrounds. Whether our disabilities are progressive or stable; whether they're visible or hidden; whether they're life-threatening; whether they're clearly diagnosed or mysteries to Western medicine; whether they cause us pain; whether they break up regular sleeping and eating patterns; whether we grew up with them or they were caused by disease or accident later in life." 
graph, constitutes an inclusive theological foundation for anthropology of interdependence and care.

\section{A Trinitarian anthropology}

Reinders pleads for a revaluation of the trinitarian views of the three Byzantine church fathers of the third century CE, the Cappadocians, namely Gregory of Nyssa, Basil of Caesarea and Gregory of Nazianzus. Where the Western church fathers like Augustine focused on the being and unity of the triune God these Eastern theologians concentrated on the diversity and relationships of the three persons. In the last few decades a new appreciation for last-mentioned approach to trinitarian thinking and the formulation of the doctrine of the social trinity developed. ${ }^{4}$

Reinders refers with appreciation to the views on the trinity of the Greek Orthodox theologian, John Zizioulas. Zizioulas argues that God is not caused by a divine substance but by Himself, specifically by the Father. There is not a divine substance, which makes God God. His Name Yahweh, I am what I am, bears witness to this fact (Reinders 1996:3031,60-61). Zizioulas also reasons that God has an ecstatic character. Ecstacis means that God's being is determined by his radical search for communion with the other. In fact, God is communion. In Jesus Christ, who became human, we are part of this communion. In this communion God finds his true being (Reinders 1996:33).

Reinders agrees with Kant that we cannot derive specific moral rules from the trinity. He, however, reckons that the trinity does offer a normative framework for understanding our identity and purpose as human beings (1996:37). This self-understanding helps us to understand who the disabled person is and this knowledge of who we are and who the disabled are determines the way we fulfill our ethical responsibility with regard to disabled people (1996:43).

True humanity is not defined by independence and rationality, but by the willingness to enter into relationships with others. In this relationship with the other you do not discover a replica of yourself, as Aristotle taught. In the interaction with the other, in the communion, in the relationship, I find my essence and being. I receive my being from the other. We receive our existence out of the hands of the other and my existence is meaningful because there are others who want to share their existence with me (Reinders 1996:34-35,43). Reinders argues that we need hermeneutical skills to appropriately understand the other, especially people with disabilities, who are viewed as inferior in terms of the modernistic paradigm. These skills enable us to view the other as someone who helps to constitute my essence as person. It resists denying the uniqueness of the other and it resists the modernistic temptation to see our task with regard to the disabled as one of determining and developing their potential for rational and independent living as the pedagogic approach to the disabled of the last decade strives to do (Reinders1996:17, 42-43).

To receive my being, my personhood from the other implies that I am dependent and vulnerable. Those who live so ecstatically can merely trust that this ecstatic living does not imply the loss of myself but the true finding of myself (Reinders 1996:38-39). Hauerwas' view of God as the God of sacrifice, of weakness and suffering who draws people to Him not by coercive power but by sacrificial love comes to mind. This genuine weakness lures us from our pretentious attempt to make our lives meaningful through power and violence. This weakness also entails that we do acknowledge that our attempt to eliminate the

4. Various prominent authors are pleading for a revaluation of the doctrine of the social trinity, amongst others Moltmann, Van Ruler, Berkhof, Gunton, Welker and Peters. 
suffering of sick and disabled people - instead of being present to them, being available for them and personally caring for them - is merely a demonstration of our quest to affirm our own significance through power (Hauerwas $1986: 13 ; 1987: 592)$. During the $20^{\text {th }}$ century with its astronomic level of suffering various theologians described Gods power in terms of this vulnerability, i.e. Berkhof, Kitamori, Sölle, Moltmann (cf. Durand 1976).

Human dignity does not reside in self-determination, but precisely in the opposite, in determination by the other. Those who recognize their dependence on the other will never view the dependence of others as a sign of their inferiority as human beings (Reinders 1996:38). They will rather recognize the call to humanity that these people offer (Hauerwas 1987:592). Smith is of opinion that this dependence on other people, specifically disabled people, opens the door for a theology of receiving. It requires a revaluation of the dominant theological position that teaches that it is better to give than to receive. She quotes a disabled woman who writes: "Can the church not bless my receiving as sacramental as much as your giving, i.e. your helping me?" (Smith 1992:36). The church will only respond adequately to this challenge if Christians acknowledge their dependence on each other and if this dependence and vulnerability and suffering are not viewed in a negative light. Where the interdependence of so-called normal or able persons and disabled people are recognized, the theology of receiving and the fact that disabled people are actually rather otherly abled people (as indicated in the title of this paper), are cherished.

The above-sketched approach that focuses on identity questions, on "Who?" questions, "Who is God?", "Who are the caregivers and who are the disabled?", transcends not only the narrow approach to morality. It also differs from the approach of somebody like the North American theologian, James Gustafson, who makes room for religion, specifically the Christian faith, in his ethical approach. Gustafson suggests a general moral directive that determines our ethical choices with regard to disabled people. He argues that we recognize that human beings have the vocation, calling, moral ideal or obligation to be there for others as well as for oneself. He quotes the love commandment and the so-called golden rule, "Do unto others as you would have others do unto you", in support of this position. This general principle of Judaism and Christianity serve as moral directive for determining an adequate ethical response to disabled people. It shapes a bias toward the well being of the other against inconvenience or cost to oneself (Gustafson 1987:488). With an appeal to this biblical principle, Gustafson (1987:486) argues that we care for the mentally retarded because of their dependence on us. However, he misses the point of our dependence on them as persuasively argued by Reinders.

The famous North American philosopher Alasdair MacIntyre (1999:3) builds with appreciation on the work of, amongst others, Reinders. He is of opinion that this emphasis on dependence is a highly neglected theme in Western moral philosophy. ${ }^{5}$ MacIntyre states that when there is reference to disabled people in the pages of moral philosophy books, they are sketched as subjects of benevolence - as becomes clear from the position of Gustafson above - whilst so-called normal people are portrayed as continuously rational, healthy and untroubled (1999:2). MacIntyre argues that there is no human being who does not experience dependence and vulnerability in his or her life. ${ }^{6}$

5. "From Plato to Moore and since there are usually, with some rare exceptions, only passing references to human vulnerability and affliction and to the connections between them and our dependence on others ... Dependence on others is of course often recognized in a general way, usually as something that we need in order to achieve our positive goals. But an acknowledgement of anything like the full extent of that dependence and of the ways it stems from our vulnerability and our afflictions is generally absent" (Reinders 1999:1-3).

6. He articulates this inclusive understanding of dependence as follows: "This dependence on particular others for protection and sustenance is most obvious in early childhood and in old age. But between these first and 
In the final section of this paper the implication of the above-outlined moral discourse about the disabled for public morality in the South African society is investigated. The implications for bio-ethics were already outlined in the previous paragraphs.

\section{Implications for a public morality}

The revaluation of our understanding of morality, humanity and of God has remarkable implications for the morality of society. The ethical discourse in the context of our young democracy is dominated by the questions of the so-called narrow morality. The moral problems that South Africa has to face indicate that this narrow approach to morality is not sufficient. The discourse about disabled persons teaches us that we need to ask questions derived from the wide morality as well, questions related to who we are and what type of society we want to be. Emphasis on human rights is not enough. We also need to ask questions related to the nature of right human beings and right societies, and to the formation of such human beings and societies. The discourse about disabled people challenges theology, churches, schools, the media and other institutions of civil society to address the challenge of moral formation. The high level of moral disintegration in our society indicates that a lot of moral malformation is taking place. The need for moral formation is big.

The trinitarian-based anthropology of interdependence, vulnerability, weakness, finitude and exposure to the reality of contingency and suffering does have tremendous implications for our public morality. A few examples are cited.

The description of male and female relations in terms of interdependence and vulnerability opens the door for the breakdown of the dominance of males and the perpetuation of the naked and subtle oppression of women. Even misogyny, the hatred and stereotyping of, the prejudice against and suppression of women, that is fed by the vision of the independence and autonomy of males, can then be addressed more fruitfully. ${ }^{7}$ Homophobia can also be addressed if the interdependence between homosexual and heterosexual persons is recognised. The North American ethicist J Nelson pleads that heterosexual persons learn from homosexual persons about commitment and fidelity in relationships in the midst of a situation of fragility, i.e. a situation of stereotyping, victimization and demonization (1989).

With regard to the addressing of economic problems, MacIntyre pleads that society does not function with the politics of competing interests, but the aim should rather be that the interest of all should be met. This will happen if the basic question relates to the basic resources that each individual and group needs to make their particular contribution to the common good. This will lead to a situation where the gap between rich and poor will be relatively small (MacIntyre 1999:144), where labour mobility is limited for the sake of stable families and other institutions that will help to create and sustain a community that is a network of giving and receiving, where investment is also made in types education that is not economically productive, and where everyone takes their turn in performing the tedious

last stages our lives are characteristically marked by longer or shorter periods of injury, illness or other disablement and some among us are disabled for their entire lives" (Reinders 1999:1). This inclusive understanding of disability and dependence leads to the following conclusion about public morality: “.. consequently our interest in how the need of the disabled are adequately voiced and met is not a special interest, the interest of one particular group rather than of others, but rather the interest of the whole political society, an interest that is integral to their conception of their common good" (Reinders 1999:130).

7. In an article entitled, Misogyny and homophobia: The unexplored connections, the North American theologian, Beverly Harrison (1994), identifies the notion that males are independent and rational, whilst females are weaker, less intellectual and dependent on males as the cause of misogyny. She even links misogyny with homophobia and argues that homophobia exists because of the fact that women are viewed as inferior to men. The cause of discrimination against homosexual persons is the fact that their behavior is viewed as similar to those of women. 
and the dangerous jobs in order to avoid social inequality. These goals of interdependence, of giving and receiving, that are to be pursued in households, workplaces, schools and parishes are in conflict with the goals of a consumer society and they are, of course, utopian standards. These standards are often not realized outside Utopia, and only then in flawed ways. "But trying to live by Utopian standards is not Utopian" (MacIntyre 1999:145).

Like Hauerwas (cf. A community of character), MacIntyre (1999:146) argues that a community where this morality of giving and receiving that is based upon an anthropology of interdependence exists, would show hospitality to children:

And as it is with the care needed by children, so it is too with the care needed by the old and the mentally and physically infirm. What matters is not only that in this kind of community children and the disabled are objects of care and attention. It matters also and correspondingly that those who are no longer children recognize in children what they once were, that those who are not yet disabled by age recognize in the old what they are moving towards becoming, and that those who are not ill or injured recognize in the ill an injured what they often have been and will be and always may be. It matters also that these recognitions are not a source of fear. For such recognitions are a condition of adequate awareness of both the common needs and the common goods that are served by networks of giving and receiving and by the virtues, both of independence (because everyone has something to offer - NK) and of acknowledged dependence. Yet that awareness cannot itself be achieved without those same virtues.

It is clear that further investigation of the moral implications of the theological response to MacIntyre's anthropology of giving and receiving, of interdependence, i.e. a trinitarianbased anthropology of interdependence and vulnerability, may help modern-postmodern societies in addressing their immense moral challenges. Failing to do this may lead to a situation where we as society, regardless of our accomplishments, cannot claim to be worthy and humane (Hauerwas 1987:593).

\section{BIBLIOGRAPHY}

Birch, B and Rasmussen, L 1989. Bible and ethics in the Christian life. Augsburg: Minneapolis.

Durand, JJF 1976. Die lewende God. Pretoria: NG Kerkuitgewers.

Gunton, C 1991. The promise of trinitarian theology. Edinburgh: T\&T Clark.

Gunton, C 1993. The One, the Three and the Many. God creation and the culture of modernity. Cambridge: Cambridge University Press.

Gustafson, J 1987. Mongolism, parental desires, and the right to life. In: Lammers, SE and Verhey, A (eds.): On moral medicine: theological perspectives in medical ethics. Grand Rapids: Eerdmans

Harrison, B 1994. Misogyny and homophobia: The unexplored connections, In: Boulton, W et.al. (eds.): From Christ to the world. Introductory readings in Christian ethics. Grand Rapids: Eerdmans, p.331-341.

Hauerwas, S 1993. Abortion theologically understood. In: Stallsworth, PT (ed.): The Church and Abortion: In Search of a New Ground for Response, 44-66. Nashville: Abingdon.

Hauerwas, S 1987. The Christian, society and the weak: A meditation on the care of the retarded. In: Lammers, SE and Verhey, A (eds.): On moral medicine: theological perspectives in medical ethics. Grand Rapids: Eerdmans 
Hauerwas, S 1986. Suffering presence, Theological reflections on medicine, the mentally handicapped, and the church. Notre Dame, Indiana. University of Notre Dame Press.

Hauerwas, S 1981. A Community of Character: Toward a Constructive Christian Social Ethic. Notre Dame: University of Notre Dame Press.

Koopman, N 2000. Dade of deugde? Implikasies vir Suid-Afrikaanse kerke van ' $n$ modern-postmoderne debat oor die moraliteit. Unpublished dissertation University of the Western Cape.

Kuitert, HM 1981a. Pluraliteit van moraal in de christelijke gemeente. In: Vlijm, JM (red.), Geloofsmanieren; studies over pluraliteit in de kerk, 237-278. Kampen: Kok.

Kuitert, HM 1981b. De rol van de bijbel in de protestantse theologische ethiek. Gereformeerd Theologisch Tijdschrift 81, 65-82.

Kuitert, HM 1984. Spelen godsdienstige overtuigingen een rol bij de morele oordeelsvorming? In: Musschenga, AW (red.): Onderwijs in natuurwetenschappen en morele vorming. Opstellen over wetenschaps-filosofie, theologie, antropologie en ethiek voor het natuurwetenschappelijk onderwijs, 206-219 Amsterdam.

Kuitert, HM 1985. Alles is politiek, maar politiek is niet alles. Een theologisch perspectief op geloof en politiek. Baarn: Ten Have.

Kuitert, HM 1987. De Politiek in de Theologie, een uit de hand gelopen actualisering of het passeren van een wissel? GTT 87/1, 40-46.

Kuitert, HM 1988. Morele consensus: mogelijkheden en grenzen. In: De Beaufort, IG en Dupuis, HM (reds.): Handboek Gezondheids-ethiek, 29-40. Assen/Maastricht.

Kuitert, HM 1988. Secularisatie en moraal. In: Dekker, G en Gäbler, U (reds.): Secularisatie in theologisch perspectief, 31-148. Kampen: Kok.

Kuitert, HM 1989. Autonomie: een lastige laatkomer in de ethiek. Een kapitteltje mensbeeld en moraal. Afscheidscollege. Amsterdam: VU Boekhandel.

Kuitert, HM 1994. Geloof en moraal als mensenwerk. In: Van Leeuwen, E (red.): Ethiek tussen hemel en aarde. Essays over de theologie en ethiek van H.M. Kuitert, 21-44. Baarn: Ten Have.

MacIntyre, A 1999. Dependent rational animals. Why human beings need the virtues. London: Duckworth

Moltmann, J 1980. Trinität und Reich Gottes. zur Gotteslehre. München: Chr. Kaiser.

Musschenga, A 1994. De universele moraal als opdracht. In: Gäbler, U et.al. (eds.): Geloof dat te denken geeft. Baarn: Ten Have.

Nelson, J 1989. A response to aids. In: Peters, T (ed.): God as trinity. Relationality and temporality in divine life. Louisville: Westminster/John Knox Press.

Rasmusson, A 1994. The Church as Polis: From Political Theology to Theological Politics as Exemplified by Jürgen Moltmann and Stanley Hauerwas (Studia Theologica Lundensia 49) Lund: Lund University Press.

Reinders, J 2000. The future of the disabled in liberal society, an ethical analysis. Notre Dame, Indiana.University of Notre Dame Press

Reinders, J 1996. Wat niets kan worden, stelt niets voor. Mensen met een ernstige verstandelijke handicap in het licht van de hedendaagse gezondheidsethiek. Amsterdam: Vrije Universiteit 
Reinders, J 1993. De bescherming van het ongeboren leven. Morele en godsdienstige overwegingen bij experimenten met menselijke embryo's. Baarn: Ten Have.

Smedes, L 1991. Choices. Making right choices in a complex world. San Francisco: Harper.

Smith, C 1992. Preaching as weeping, confession, and resistance: radical response to radical evil. Louisville, Kentucky. Westminster/John Knox Press. 